\title{
The Indus Delta Between Past and Future: Precarious Livelihoods and Neoliberal Imaginaries in a Parched Coastal Belt
}

\author{
Hasan H. Karrar \\ Lahore University of Management Sciences
}

\begin{abstract}
The Indus delta, at the terminus of the Indus river system, is presently home to 300,000 residents. Over the last century, upriver hydrology has reduced the flow of water through the river. The result is salination and seawater incursion that has led to the loss of arable land and with it, agriculture as a sustainable livelihood. This has created precarious livelihoods, as people are forced either into the informal fishing sector, or to migrate; this is a departure from earlier times when agriculture was the primary vocation, and forests covered large swathes of the region. I also discuss future plans for port development in the delta that is constitutive of a neoliberal developmentalist imaginary. This vision, in which a future Pakistan will be connected to markets in Asia through its ports, has been propagated for decades, and most recently as a consequence of China's ongoing investment regime in Pakistan. In the conclusion, I reflect on the paradox of fixation on fantastical futures while the population is caught up in an uncertain present.
\end{abstract}

The story in this article pivots between two port cities in the Indus delta, neither of which exist today. ${ }^{1}$ The first is a place as it is popularly recalled. This Indian Ocean port cityKeti Bunder-was located in Pakistan's southern Sindh province. ${ }^{2}$ While there is still $a$

\footnotetext{
${ }^{1}$ Shortly before this article was published, Mohammad Ali Shah, chairperson of the Pakistan Fisherfolk Forum (PFF) passed away. For decades, Mohammad Ali Shah had highlighted the precarious livelihoods of coastal communities and the environmental degradation creeping across the Indus delta. A grassroots activist, he also cautioned against megadevelopment projects, the disappearance of commons, and large-scale commercial fishing. I will remain indebted to Mohammad Ali Shah, who first introduced me to the complex ecology of the Indus delta, and the manner in which it is embedded in a long history of state building.

${ }^{2}$ Other Indus delta ports, such as Lari Bunder and Shah Bunder followed Keti Bunder's broad historical trajectory; these places would suffer a similar fate due to change in physical environment.
}

(C) Hasan H. Karrar. This is an Open Access article distributed under the terms of the Creative Commons License CC BY NC SA, which permits users to share, use, and remix the material provided they give proper attribution, the use is noncommercial, and any remixes/transformations of the work are shared under the same license as the original. 
Keti Bunder today, with a population of about 28,000, the current settlement is dismissed as a shadow of its past self. The former Keti Bunder, that is described as having been networked to other Indian Ocean port cities, is said to have existed until the early twentieth century when it was engulfed by encroaching sea water. This forced the residents to relocate inland. According to local accounts, this second city too was swallowed by the sea, the local populace now scattering yet further inland. Keti Bunder - the coastal community that exists today - is said to be the third iteration of this once cosmopolitan coastal community.

Juxtaposed alongside descriptions of past abundance are plans for a fantastical port city and industrial complex that will purportedly one day be built in the Indus delta. This neoliberal development imaginary, that has been iterated since 1995, has been variously described, most popularly as a future port city by the name of Zulfiqarabad. Construction of such a futuristic port city is yet to begin; for a quarter of a century, it has existed solely in the imagination of Pakistan's technocratic planners. This is a neoliberal vision of the future that will allow Pakistan to tap into market-driven, transnational capital; once infrastructure capacity is realized through port-building, incoming finance is said to transform Pakistan. Over the last quarter century, promises of unrestricted capital, merchandise and investment across nation-state boundaries have periodically undergirded a privatization ethos in Pakistan. ${ }^{3}$ Unsurprisingly then, port development has been variously projected as the building of a new Dubai or Shenzhen; both are Asian cities whose fortunes were transformed in living memory through foreign investment. ${ }^{4}$ In the 1980s and 1990s it was the Gulf states that were seen as the locus of market-driven growth in Asia; today it is China.

New infrastructure capacity, primarily ports, are essential to this vision. In how they are depicted, ports, in fact, may be the quintessential networked spaces that will engender a new prosperity. The promise of connectivity is the raison d'être for port building. By contrast, in Keti Bunder today, most of the inhabitants along the coast (Urdu: sāhll) are

\footnotetext{
${ }^{3}$ Aasim Sajjd Akhtar, "Privatization at Gunpoint," Monthly Review, 55, 5 (2005), 26-33.

${ }^{4}$ In this, Pakistani state aspirations for a regionally-networked Indus delta have been similar to how state officials projected prosperity through port building in the Karakoram high mountain region, where a dry port had been inaugurated in 2006 outside the north Hunza village of Sost. According to the then ruling junta and their technocratic advisors, the Sost dry port would have connected Pakistan to Afghanistan, Central Asia, India, Iran and the United Arab Emirates ("Pak-China Commerce set for rapid growth: Musharraf inaugurates Sust dry port," Business Recorder (5 July 2006): https://fp.brecorder.com/2006/07/20060705447147/ [Accessed: 29 Dec. 2019]). Similar benefit is also anticipated from the Gwadar port in Pakistan's Baluchistan province, where following the port's handover to the China Overseas Port Handling Company in 2012, the small fishing community has been suddenly transformed into a central node in a region that is defined by Chinese supplier and financial networks (Liu Caiyu, "Gwadar Port Industrial Zone will benefit wider region," Global Times (3 Feb 2016): https://www.globaltimes.cn/content/967253.shtml [Accessed: 16 Aug. 2021]
} 
forced to eke out a precarious living in the informal fishing sector. ${ }^{5}$ A little further inland, people tend small herds of livestock, or laboriously work parched land. The landscape is uninviting: traveling towards the coast, dull shrubbery turns to salt flats. Dotting this unwelcoming terrain are shacks - people's homes - and pools of stagnant water, the only source of non-saline water that is rationed for consumption by humans and livestock.

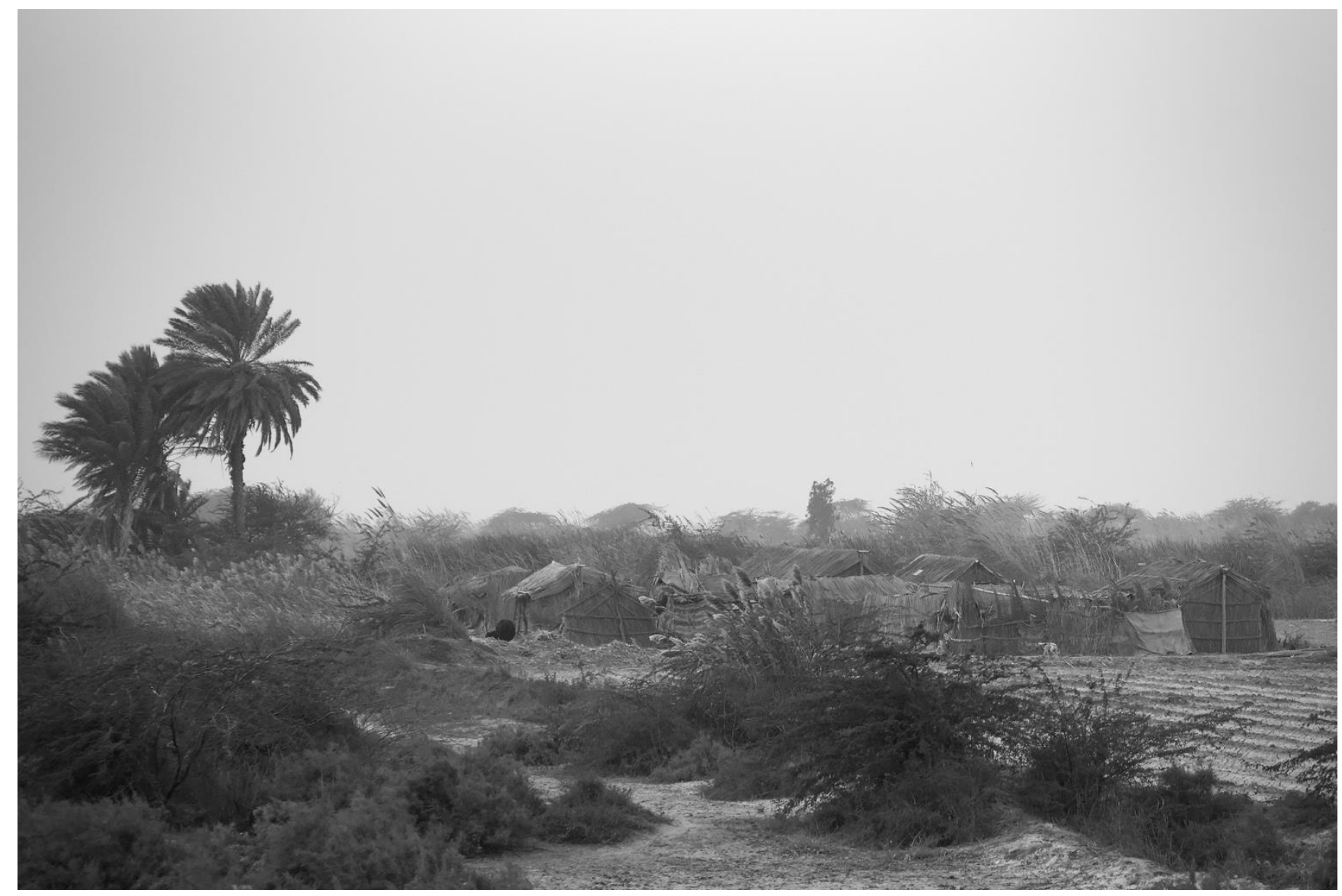

Fig. 1. In inland sections of the Indus delta, people eke out a living cultivating small tracts of land. Photo courtesy of the author.

The Indus delta is an unremarkable place: the population is small, and the economy is localized. Since at least the formation of Pakistan, it has been peripheral to global, or even regional capital flows. Neoliberal developmentalist imaginaries, on the other hand, allow this unremarkable place to be reimagined as a gateway for transnational capital.

\footnotetext{
${ }^{5}$ Author interviews, 2018-2020; Amir Guriro, "Keti Bunder- the town that never became the third port of Sindh," Pakistan Today (July 2011): https://www.pakistantoday.com.pk/2011/07/18/keti-bunder--the-town-that-never-became-the-thirdport-of-sindh/ [Accessed: 2 September 2019].
} 
These two stories - irrelevance to the economy at large versus state-propagated neoliberal futures - intersect in the Indus delta.

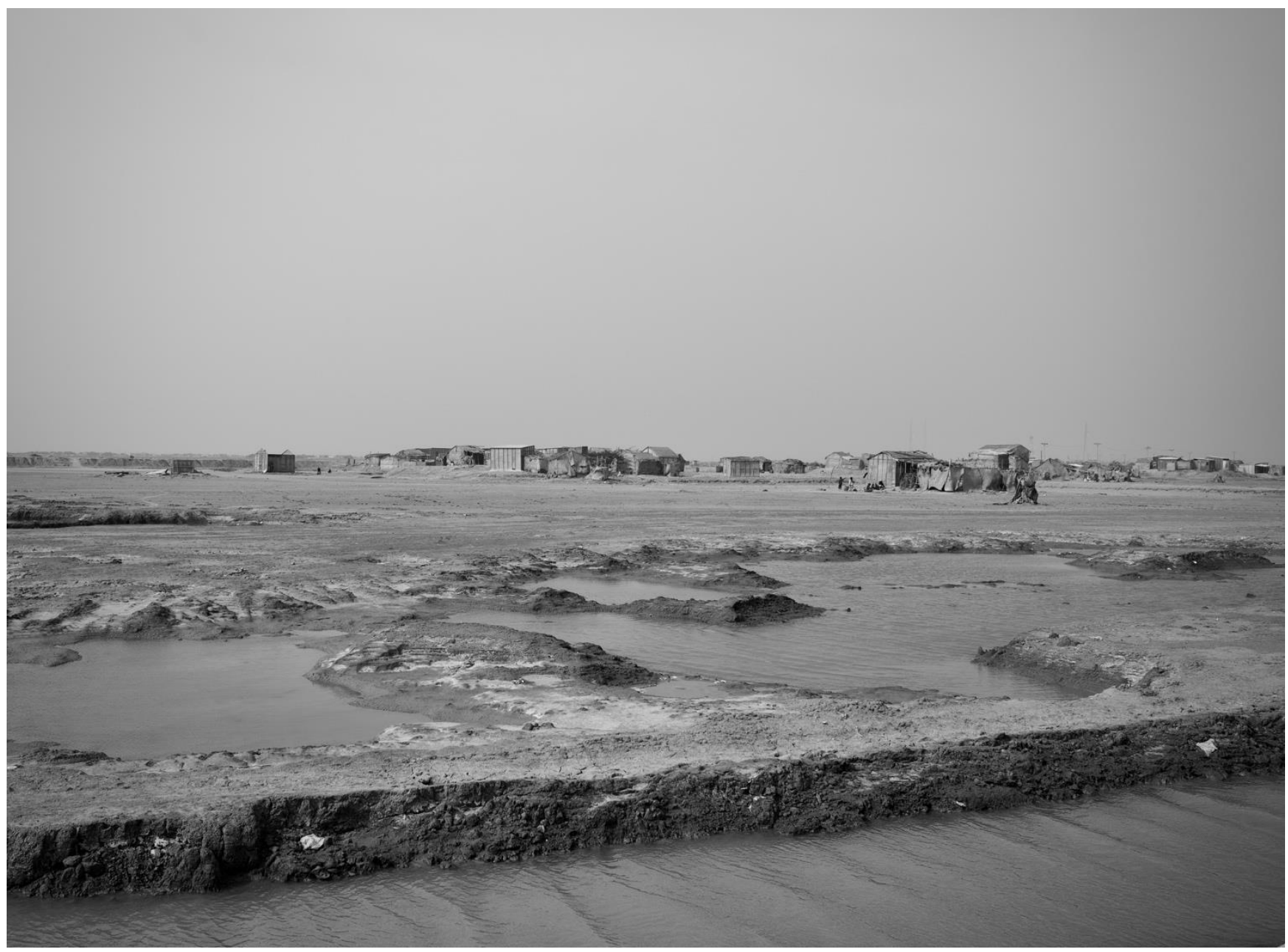

Fig. 2. Salination of the topsoil has laid waste to large tracts of coastal land in the Indus delta. Photo courtesy of the author.

Caught in between the ground reality and the technocratic vision is a 300,000 strong population that is vulnerable from land loss and salination due to seawater incursion and declining water levels in the Indus, a veritable disaster that has played out in slow motion over the last century. The people I have spoken with in the Indus delta contest any notion of natural environmental scarcity, or of unchecked population growth putting a strain on resources. Rather, their position is similar to what political ecologists would argue: that water scarcity - like any contestation over finite resources - is actually about 
power. ${ }^{6}$ The delta residents do not have enough water because they are less powerful than both upriver Punjab, as well their neighbouring districts in upper and central Sindh.

There is nothing natural about the disaster that has been unfolding in the Indus delta, which, in fact, is often the case with so-called natural disasters. ${ }^{7}$ Instead, a longtwentieth-century lens reveals how environmental degradation in the Indus delta is not the result of recent developments, but is a compounded consequence of state-building through infrastructure along the Indus river system: upriver development schemes, beginning with colonial-era canal construction in the Punjab at the end of the nineteenth century, followed by barrage and dam construction in postcolonial Pakistan. Thus, upriver hydrology has critically impacted the delta, with the flow of water steadily decreasing, and at times, stopping entirely. The resulting transformations in the delta are not only environmental, but also ecological, in that they transform community, livelihood and well-being. ${ }^{8}$ With the change in the physical environment, the vocational opportunities available to people have shrunk; although there is some agriculture, as well as some livestock breeding, for the majority of people, fishing or outmigration are the only options.

This article has three parts. Part 1-Past-begins with an overview of the physical and human geography of the Indus delta. It describes how past connectivity and productivity in the Indus delta is recalled today. While I make some attempt to corroborate local recollections with colonial-era accounts, it is important to foreground that much of what was recalled for my benefit were popular memories functioning in a milieu of scarcity and precarious livelihoods. Put simply, an acute sense of depravation shapes how people remember. In part 2-Present - I trace how upriver hydrology stemmed the flow of water in the Indus delta, culminating in the present environmental disaster. I conclude this section with a short discussion of upriver developments that reduced the flow of water in the Indus, which is considered to be the primary cause of encroachment by the sea. In part 3-Future-I discuss plans for port and infrastructure development in the Indus delta that date to the 1990s. In 2010, these plans acquired new momentum, with the planned city taking the name Zulfiqarabad. Although this name was dropped in 2016, as I describe, deliberations about port development in the Indus delta began to take place under the

\footnotetext{
${ }^{6}$ Nancy Lee Peluso and Michael Watts, "Violent environments," in Violent Environments, eds. Nancy Lee Peluso and Michael Watts (Ithaca: Cornell University Press, 2001), 3-38.

${ }^{7}$ Greg Bankoff, Georg Frerks, and Dorothea Hilhorst (eds), Mapping Vulnerability: Disasters, development and people (New York: Earthscan, 2004); Kenneth Hewitt, Regions at Risk: A geographical introduction to disasters (London: Routledge, 2014).

${ }^{8}$ Ali Nobil Ahmad and Hasan H. Karrar, "Capitalism, nature, and socialism in South Asia: Perspectives on ecology from India and Pakistan," Capitalism, Nature, Socialism, 26, 3 (2015), 48-63.
} 
framework of the China-Pakistan Economic Corridor (CPEC) and the Belt and Road Initiative (BRI). Unlike the manner in which the history of the delta is recalled, in which there is an emphasis on the local, the future projections are all at a macro level, in which people do not feature. In the conclusion I unpack the paradox of fixation on neoliberal futures while a vulnerable population confronts a precarious present.

This is an exploratory article outside my field. By training and by profession, I am an academic specialist of China and Central Asia. Although the Indian Ocean world appears to be a significant shift from the regions of Asia I otherwise write about, I was struck, and remain intrigued by how futuristic imaginaries of Asian connectivity are projected onto otherwise unremarkable places. This is something I have seen in field visits to rural Kazakhstan, Kyrgyzstan and north Pakistan. ${ }^{9}$ The ethnography I describe in this essay was conducted in the summer of 2018, the summer of 2019, and the beginning of 2020. Readers might be struck by the fact that the people I spoke with all appear political. Indeed, they are. They are not political by choice, or by adherence to an ideology or belonging to a party or activist collective. Rather they are politicized by the environment, the grim, unforgiving topography of the place they call home. People who are forced to drink the same brackish water as their animals cannot but be political. When one stands on windswept salt flats and talks about the $s \bar{a} h l$, one is talking politics. Poverty and precarity are a consequence of unequal power, and for a community that had enjoyed better living in the not too distant past, this is well-understood.

\section{Past}

The Indus delta region, at the terminus of the Indus river, begins 250 kilometers before the river drains into the Indian Ocean. The provincial sub-region where the delta is located is lower Sindh, or what in local vernacular is known as $l \bar{a} r$, which also includes the coastal megacity of Karachi. Although the Karachi metropolitan area is not part of the Indus delta, the Korangi industrial area on the outskirts of city lies at the delta's northern limits.

The delta can be imagined as having two axes: one that begins in Karachi and extends about two hundred kilometers towards the interior of Sindh, roughly following the Indus by way of Gharo, Thatta and Sajawal. The other axis is seaward, running along the coastline two hundred kilometers from Karachi, towards the border with India, to Keti

\footnotetext{
${ }^{9}$ Hasan H. Karrar, "In the shadow of the Silk Road: Border regimes and economic corridor development through an unremarkable Pakistan-China border market," Comparative Studies of South Asia, Africa and the Middle East, 39, 3 (2019), 389-406.
} 
Bunder. This entire region is currently inhabited by around 300,000 people; administratively, the region is divided into three districts: Badin, Thatta, and Sujawal. Although Sindhi is the lingua franca of the Indus delta, and is also how most of the local populace describe themselves, Sindhi is not the sole vernacular, and nor are Sindhis the only ethnic group residing in the delta. This is a multiethnic region also inhabited by Baluch, Memon, and Sheedi, who besides Sindhi or Urdu, might speak Baluchi and Gujrati.

Within the delta, there is variation in both population densities, and topography. While many live in peri-urban areas such as Korangi, others are settled in towns such as Thatta (pop. approx. 100,000), and in villages that are variously located in the interior, along the coast, and on coastal islands. In addition to the towns and villages, there are scores of non-permanent settlements in the Indus delta that are also described as villages by locals: these settlements - or villages as they are called - will typically constitute two or three generations of an extended family subsisting off the land by grazing livestock, collecting and selling deadfall, or cultivating patches of land. People who work for local aid groups point out that it is virtually impossible to count the number of such settlements. Inhabitants in remote settlements have no access to public services, such as schools or hospitals.

Historically, there would have been three geological zones between the interior regions of the delta and the coast. The inland stretches - that is, those regions that were furthest from the sea-comprised of tamarisk forests that were irrigated when the river overflowed its banks; until the nineteenth century flooding had been a yearly feature. In the middle regions were mud flats. During earlier times when there was an abundance of water in the Indus, the mud flats would have been cultivated; at other times, they were covered by shrubs. Finally, in the lowest reaches of the Indus delta, that is closest to the sea, the delta was covered by mangrove swamps. ${ }^{10}$ While animal husbandry and agriculture were traditional vocational activities, forestry was also a major industry. Residents of the Indus delta proudly recall that the timber from the region powered locomotives during colonial times; although unlikely, I am told that at one time $30 \%$ of the coal used in Indian locomotives was produced from wood that grew in the delta. ${ }^{11}$

During the nineteenth century, agriculture was the primary vocation. The Indus delta was fertile because of the silt carried by the Indus river, as well as the yearly flooding,

\footnotetext{
${ }^{10}$ M.R. Haig, The Indus Delta Country: A memoir chiefly on its ancient geography and history (London: Kegan Paul, Trench, Trubner \& Co., Ltd., 1894); Arif Hasan, "The death of the Indus delta," The Herald (2 Aug. 1989).

${ }^{11}$ Author Interview, 2018.
} 
which irrigated inland tracts along the river. The delta produced rice, coconuts, bananas and mangos in abundance. 'It was said to be a time of plenty,' people will recall today. 'Our elders told us that a hundred years back there would have been no concept of selling milk or other dairy products. Everyone had such produce in abundance, and they were always happy to part with them. It would cost them nothing to do so.' ${ }^{12}$ In times pastand to an extent, this remains true today - variation in soil quality and access to water has meant that different parts of the region have been able to support different crops. The land in proximity to the Indus has tended to be more fertile than the coastal stretch.

The ecological effects of decreased water in the Indus are part of people's recollections of the recent past. Informants described to me how until the early 1980s, there were mango orchards in the delta. Watermelons were also grown yearly. There were also strains of rice indigenous to the delta, including a red rice strain which is no longer grown. 'Even thirty years ago it would have been unimaginable that a day would come when we would buy rice from the market,' I was told (while on the topic, market-bought rice was described as 'plastic,' a function of how everyday consumption can reinforce associations for a time and place now in the past). ${ }^{13}$ When rice cultivation became unviable due to lack of water, sugarcane took its place. When sugarcane cultivation was no longer possible, people began growing tomatoes. Shifts in cultivation serve as a timeline for decrease in water and loss of arable land. Previously, fishing only constituted a portion of the vocations available to the people, unlike in the present. The people I spoke with emphasize that in decades past, fishing was not the primary vocation; they describe themselves as having been cultivators and pastoralists, before fishing became the primary vocation. ${ }^{14}$

The nineteenth-century colonial-era accounts I have consulted seem to corroborate local descriptions. ${ }^{15}$ For example, an account by Captain James Macmurdo (d. 1820), who served as political agent to the Cutch state, described the Indus delta as 'extraordinarily fertile.' In Macmurdo's account, which appeared in the Transactions of the Bombay Geographical Society two decades after his death, the abundance of water in the Indus

\footnotetext{
${ }^{12}$ Author Interview, 2019.

${ }^{13}$ Author Interviews, 2019.

${ }^{14}$ Author Interviews, 2019.

${ }^{15}$ Sindh was conquered by the East India Company in 1834, ending the rule of the Talpur Mirs. Earlier, in 1830, Alexander Burnes (d. 1841) navigated the Indus northward, under the pretext of presenting of delivering royal gifts to Raja Ranjit Singh (d. 1839). Following Burnes' travels — and the conquest of Sindh soon afterwards - the East India Company began to use the Indus for upriver travel. Successive commercial treaties, for the purpose of taxation, were also imposed on the Talpurs. Besides profit, the East India Company sought to ensure that Malway opium did not make its way to Portuguese harbors in Gujrat. See: Manan Ahmed Asif, A Book of Conquest: The Chachnama and Muslim origins in South Asia (Cambridge, MA: Harvard University Press, 2016), 159-60.
} 
delta was a defining characteristic. Flooding was an annual feature between May and September, following snow melting in the Himalaya and the monsoons. ${ }^{16}$ Less a hazard, flood water, which usually inundated land six to eight miles on either side of the river bank, was channelled through canals for use yet further inland. ${ }^{17}$ The same account also described the abundance of food in the Indus delta. Consider the following:

The crops produced in this tract ... are said to be beyond anything luxuriant, and so extensive that nothing is perceptible for miles, but a vast expanse of grain excepting ... sheets of water of several miles in extent. Such is the abundance of crop ... that no boundaries distinguish the property of one cultivator from that of another, each individual scattering and reaping his grain at hazard. ${ }^{18}$

Although ever-shifting water levels meant that the topography of the Indus delta was regularly changing, in the nineteenth century it was estimated that there was a net gain of about four meters every year as flows in the Indus pushed the sea outward. ${ }^{19}$ Before barrage construction upriver began in the 1930s, water discharge from the Indus river was said to extend 50 kilometers into the sea.

Until the nineteenth century, the Indus delta was also a commercial hub. The Indus delta ports of Keti Bunder and Shah Bunder were visited by dhows from the Persian Gulf. Customs revenue was collected at Keti Bunder (a local resident described seeing old customs ledgers floating out to sea as the incoming sea inundated old municipal buildings). Hindu bankers served as local financiers for traders. Keti Bunder is remembered as an affluent municipality - 'the city had gas lights in the 1920s,' I am told-which extended loans to Karachi municipality. ${ }^{20}$

In locals' memories, the Indus delta ports were cosmopolitan places. The people I spoke with recall with discernible pride how in the past, sojourners from across the Indian Ocean would have been present in the delta ports. These ports then appear little different from other Indian Ocean ports, where over the course of modern history mobility and

\footnotetext{
${ }^{16}$ Even outside the summer flooding, the lower stretches of the Indus carried enough water so as to be navigable down to the sea, which was allegedly used by invading Arab and Greek armies (Haig 1894, 51-53).

${ }^{17}$ James Macmurdo, "Observations on the Sindhoo or river Indus," in Transactions of the Bombay Geographical Society, from June 1839 to February 1940 (Bombay: American Mission Press, 1840), 124-34.

${ }^{18}$ Ibid., 127.

${ }^{19}$ Haig, The Indus Delta Country, 7.

${ }^{20}$ Author Interview, 2019.
} 
financing created a cosmopolitan fabric that stretched across the littoral regions of the Indian Ocean. ${ }^{21}$ These seaward linkages were dependent on inland networks, whereby produce from the Indus delta was brought to the port cities and then shipped outward to nearby Indian Ocean ports. Inland Indus delta networks tended to follow the web of creeks and waterways in the delta, each of which had a name. Besides serving as a means of transport-and hence connectivity - these water channels created a place-centric identity. ${ }^{22}$ The history of the region, and the inland networks, were contoured by the waterways of the Indus delta. This was a landscape made by water. Human settlements in the delta — and people's economic activities — contoured to it.

And yet, caution would be prudent here. By the early twentieth century, indigenous Indian Ocean networks were already being overshadowed by colonial mercantile networks. ${ }^{23}$ Put another way, a hundred years ago, the Indus delta would already have been past when it had been an Indian Ocean hub. Also, the erosion of indigenous merchant networks was unrelated to the ecological changes in the delta, although the two may sometimes be conflated in local recollections by way of emphasizing how prosperous the past had been. How the past is remembered cannot be dissociated from elsewhere, and the conditions under which, this local memory is conserved and is recalled. ${ }^{24}$ The efficacy of this discourse is in its very juxtaposition with present-day precarity, which I describe in the following section; recalling the past in particular ways also shifts the causation for poverty and underdevelopment onto development policies of the colonial and postcolonial state (in doing so, these causations sidestep immediate and localized reasons for poverty such as a credit system which keeps the fisherfolk indebted).

\section{Present}

A substantial portion of the population who live in the Indus delta are either fisherfolk or people whose livelihoods are linked to fishing. According to one estimate, 90 percent of

\footnotetext{
${ }^{21}$ See, for example: Sugata Bose, A Hundred Horizons: The Indian Ocean in the age of global empires (Cambridge, MA: Harvard University Press, 2009); Engseng Ho, The Graves of Tarim: Genealogy and mobility across the Indian Ocean (Berkeley: University of California Press, 2006); Abdul Sheriff and Engseng Ho, (eds.), The Indian Ocean: Oceanic connections and the creation of new societies (London: Hurst \& Company, 2014).

${ }^{22}$ Haig, The Indus Delta Country, 69-71.

${ }^{23}$ Rajat K. Ray, "Asian capital in the age of European domination: The rise of the bazaar, 1800-1914," Modern Asian Studies, 29, 3 (1995), 449-554

${ }^{24}$ Such local accounts of past abundance follow a much longer pattern of thinking about Sindh. As Manan Ahmad Asif notes, in the earliest Greek or Roman sources, or latter-day Arab ones, the wonders of India became synonymous with Sindh. India was the frontier on the edge of the world, and the Indus delta was the gateway to this fabulous land (Asif, A Book of Conquest, 29).
} 
Keti Bunder households depend on fishing. ${ }^{25}$ Although a commercial activity, it remains on a small scale, its community foundations evidenced in village or kin networks that constitute the basis of the fishing operations. The local service industry is also linked to fishing. One sees outboard motors being stripped apart for servicing, fishing nets being repaired, small fishing boats pulled up on dry land. It is also hard to overstate how precarious fishing can be. While there are some medium-sized trawlers, many fisherfolk operate with minimal resources. On an overcast January afternoon, I watched fisherfolk in Keti Bunder load sacks of food rations onto a boat barely twenty feet long. Even though I was well clad, it was chilling to imagine being out at sea on an open boat for days on end.

Whereas in the past the Indus delta was networked both seaward to other ports and inland, the seaward networks have disappeared and the traditional commercial networks, that rested on the distribution of local produce, have shrunk considerably; this is a consequence of industrial fishing by trawlers out at sea, and the disappearance of natural mangrove forests closer to the shore. ${ }^{26}$ In its stead are two new networks. The first of these are informal fishing networks. Fishing networks not only link the fisherfolk to the market, but also to creditors and moneylenders. Given that fishing is an equipment intensive activity-mandating regular upkeep of boats, nets, and outboard motors-fisherfolk frequently end up indebted, and are forced to sell their catch to creditors at rates which are between 20 and 30 percent below market prices. Given also that the fisherfolk in the Indus delta are small-scale operators, they end up utilizing the services of auctioneers, who charge an auction commission of between 5 and 10 percent, and more in the event that the auctioneer is also the financier. Fishing in the Indus delta is a credit driven industry with endless cycles of borrowing and repayment. ${ }^{27}$ Fishing is also a hierarchical industry with bottlenecks: there are limited auctioneers in the delta, and a local elite determines who can fish in which sector. Access — or lack of access - to fishing blocks is described similarly to the feudal-tenant landholding system in central and upper Sindh. ${ }^{28}$

\footnotetext{
${ }^{25}$ Umair Shahid, "Making a sustainable living from fishing in the Indus delta," WWF-Pakistan (19 Mar. 2013): https://wwf.panda.org/?207962/Making-a-sustainable-living-from-fishing-in-the-Indus-Delta [Accessed: 23 Aug. 2020]. ${ }^{26}$ Rina Saeed Khan, "Death of the Indus delta," Lead Pakistan (Undated): http://www.lead.org.pk/hr/attachments/Compandium/04_Environmental_Rights/Death_of_the_Indus_Delta.pdf [Accessed: 31 Dec. 2019]. See also: Rinku Roy Chowdhury, Emi Uchida, Luzhen Chen, Victor Osorio, and Landon Yoder, "Anthropogenic drivers of mangrove loss: Geographic patterns and implications for livelihoods," in Mangrove Ecosystems: A global biogeographic perspective, eds. Victor H. Rivera-Monroy, Shing Yip Lee, Erik Kristensen, and Robert R. Twilley (Cham, CH: Springer, 2017), 275-300.

${ }^{27}$ Shahid, "Making a sustainable living."

${ }^{28}$ Indus Delta: An environmental assessment (PFF, 2005), 25-27
} 


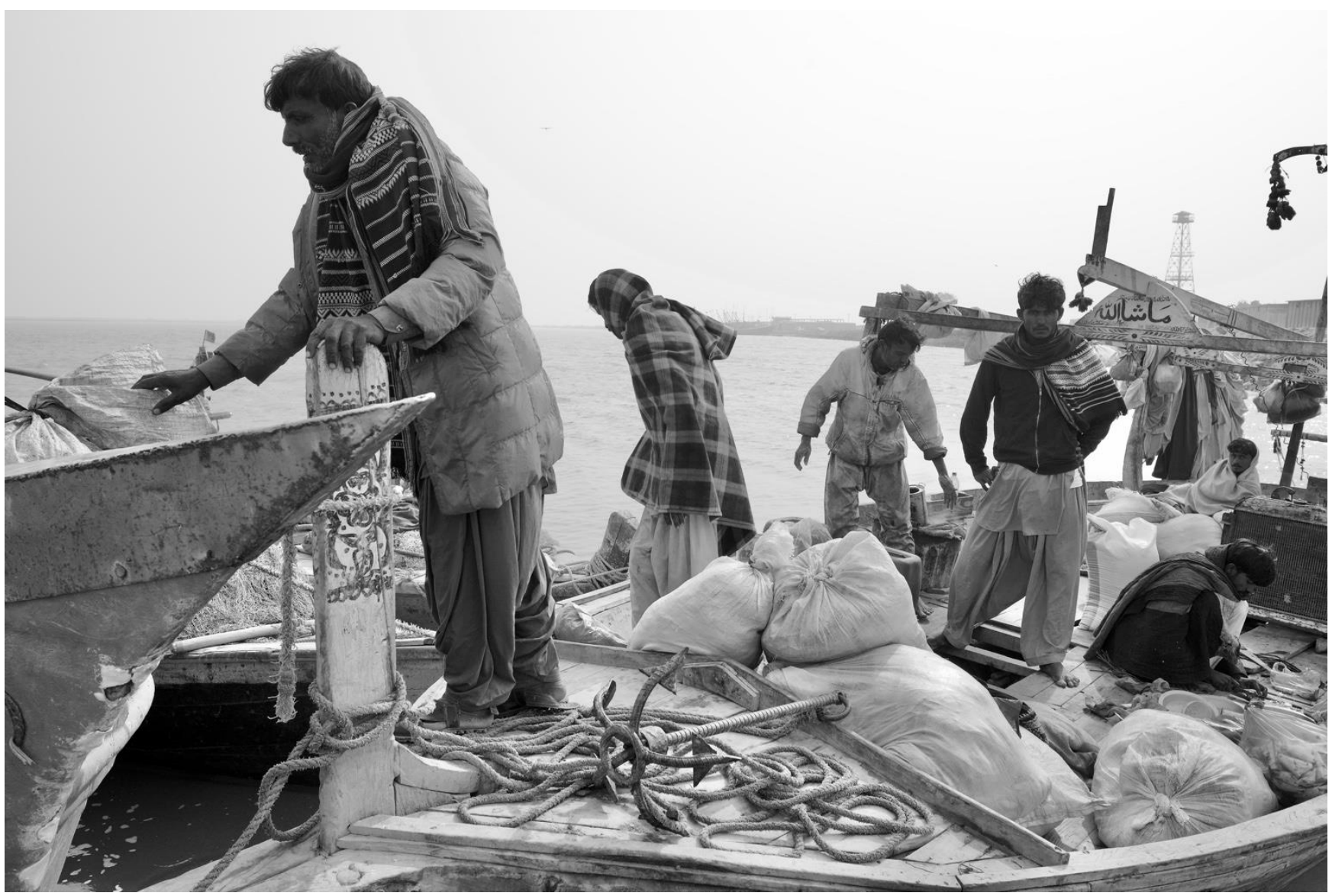

Fig. 3. Fisherfolk preparing to head out to sea. Note the open boat, on which they will be spending multiple days. Photo courtesy of the author. 


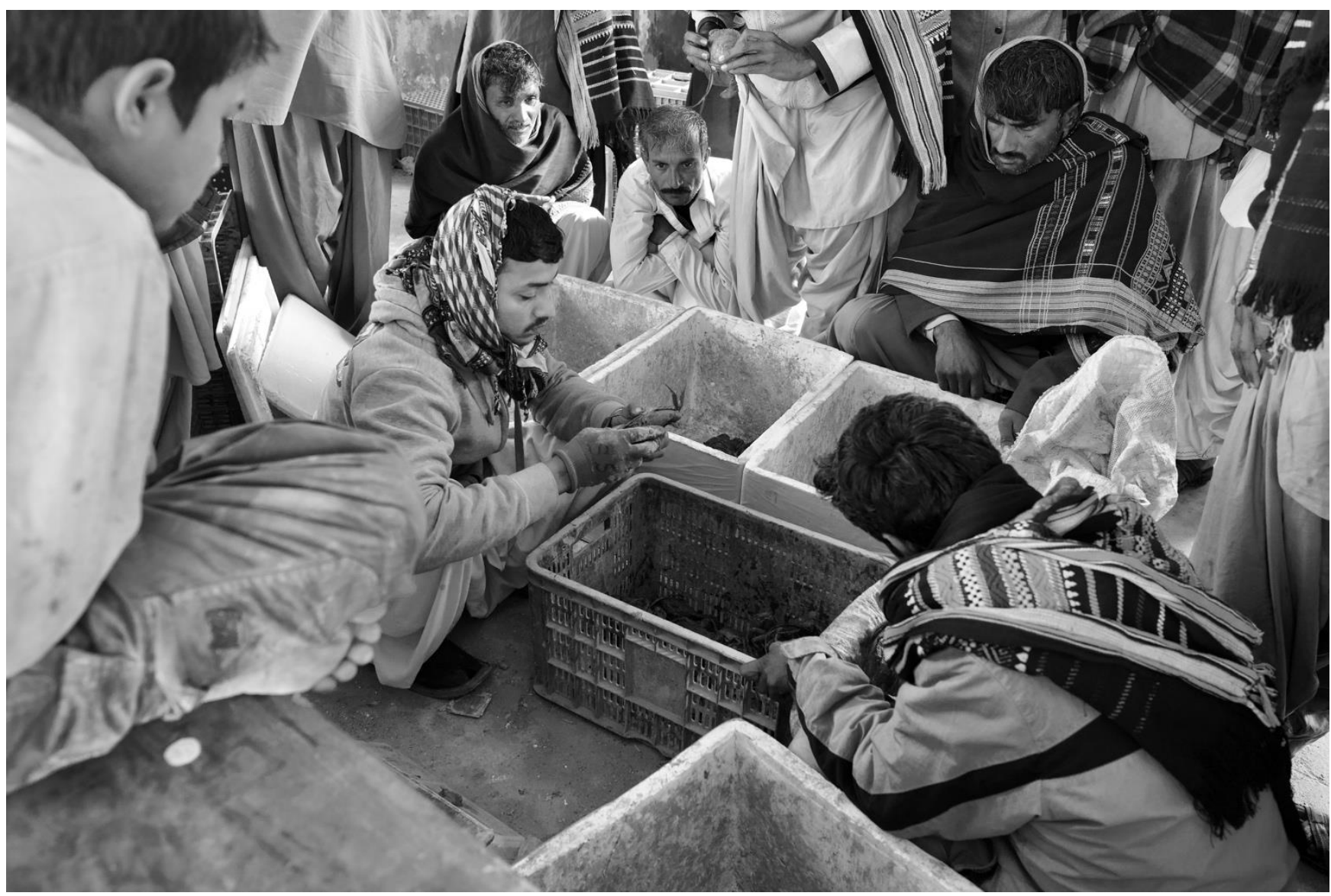

Fig. 4. A wholesaler sorts crabs based on their size and weight while local fisherfolk look on. Photo courtesy of the author.

The second network is migration out of the Indus delta. Not only have vocational opportunities shrunk, but in many parts of the Indus delta, basic services such as potable water or sanitation do not exist. As we noted, fishing is becoming less viable - according to one estimate, up to 70 percent of the fish stocks may have been depleted - and coastal residents are in a continuous battle with encroaching seawater. ${ }^{29}$ Unable to increase the flow of water through the Indus delta, residents along the coastal stretches of the Indus delta have resorted to building embankments to hold back seawater. While embankments hold back surface water, seawater makes its way inland as rising groundwater. The result is salination, which has made the land unsuitable for agriculture. There is varying empirical data for loss of agricultural land along the coastal regions: one study notes that around Keti Bunder, only eight percent of the people earn a living through agriculture; ${ }^{30}$

${ }^{29}$ Durgeshree Raman, "Damming and infrastructural development of the Indus river basin: Strengthening the provisions of the Indus Waters Treaty," Asian Journal of International Law, 8, 2 (2017), 1-31.

${ }^{30}$ Khan, "Death of the Indus delta." 
other figures for the loss of fertile land due to seawater incursion range from 550,000 acres to 3.5 million acres since $1956 .{ }^{31}$ As a consequence, there is a steady outmigration from the Indus delta, with most of the residents moving to either Thatta or Karachi, in particular to the peri-urban region of Korangi, which is the northernmost extent of the Indus delta. Of the original 42 dehs or revenue collection units, only 14 remain; the remaining have been abandoned. ${ }^{32}$

Behind the collapse of traditional vocations and the outmigration is a historical process that has unfolded over a century: the drying of the lower stretches of the Indus. According to data from the International Union for the Conservation of Nature (IUCN) the flow of water in the Indus decreased from 105,000 million cubic meters (MCM) in 1932 to 43,000 MCM by 1970, and was reduced yet further to 12,300 MCM in the 1990s. ${ }^{33}$ According to another source, prior to 1947, the average fresh water flows through the Indus delta were about 150 million acre feet per year. By 2002, this had dropped to 0.9 million acre feet per year. ${ }^{34}$ The last year water was said to have flowed freely through the Indus delta was during the floods of 2010. Otherwise, the yearly free flow of water through the Indus delta is said to have ceased decades ago. Put in stark terms, for about half a century, there has been scant water in the last run of the Indus, and for much of the year, the final stretches of the river and the delta creeks are parched.

The drying of the delta results from a century of upriver hydrology. Upriver hydrology had resulted from an earlier epoch of infrastructure planning and development - initially the colonial, and then the post-colonial state-along Indus water system of rivers that consists of five upriver left-bank tributaries (Jhelum, Chenab, Ravi, Sutlej and Beas) and one right bank tributary (Kabul). The flow of water through the delta started to decrease as early as 1890 with the advent of canal irrigation in the Punjab. This story is well-told and need only be described in broad strokes here. ${ }^{35}$

The Punjab was annexed by the British in 1849, bringing Ranjit Singh's kingdom, with its capital in Lahore, to an end. With British control came a more aggressive revenue extraction schema, pushing cultivators in the Punjab into a moneyed economy. In this

\footnotetext{
${ }^{31}$ M. M. Anwar, N. H. Chandio, and M. N. Bhalli, "Economic deprivation of Indus river delta, Sindh, Pakistan: Causes and suggestions," Science International (Lahore), 26, 2, (2014), 885-90; Sara Hayat, "What happens when the Indus doesn't reach the sea?," Dawn (18 Sep., 2019): https://www.dawn.com/news/1505725 [Accessed: 31 Dec. 2019].

${ }^{32}$ Guriro, "Keti Bunder."

${ }^{33}$ Raman, "Damming and infrastructural development," 3-4.

${ }^{34}$ Indus Delta: An environmental assessment, 39

${ }^{35}$ Imran Ali, The Punjab Under Imperialism, 1885-1947 (Princeton: Princeton University Press, 1988); David Gilmartin, Blood and Water: The Indus river basin in modern history (Berkeley: University of California Press, 2015); Ian Talbot, "The Punjab under colonialism: Order and transformation in British India," Journal of Punjab Studies, 14, 1 (2011), 3-10.
} 
process, the so-called agricultural castes grew indebted; it was this demographic that the British saw as their steadfast political bulwarks, and it was this economy that the British sought to extract from. Hence there was dual challenge: how to ensure a steady stream of revenue from the Punjab, essential for the running of the colonial state, and how to ensure the loyalty of the Punjab cultivators, who were seen to be compradors of the colonial state. ${ }^{36}$

The result would be canal colonies, an extensive irrigation project that covered the western stretches of the Punjab (now in Pakistan). This was a region that lay beyond the reach of the monsoons, and was as yet uncultivated. Crucially, the new canals were perennial, rather than seasonal. The purpose of these canals was to inundate 'waste' lands and bring new tracts of land under cultivation. ${ }^{37}$ At the time, canal colonies constituted one of the largest hydraulic engineering schemes in Asia. ${ }^{38}$ Hydrology continued to be important in the post-colonial state, and was in step with the so-called Green Revolution during the early Cold War: the Kotri barrage was completed in 1955, and the Guddu barrage in in 1962. The completion of Tarbela dam (in 1967) and the Mangla dam (in 1974) were not only amongst the largest dams in Asia, but were undertaken at considerable cost to the state. ${ }^{39}$

The result of these developments has been a steady decrease in water flows and silt through the Indus delta. Besides the drying up of the delta, the lack of water in the lower stretches of the Indus has resulted in delta residents being critical of upriver hydrology. David Gilmartin sees discord over water as provincial discord, only presenting as a different frame. Writing about upstream dams, he writes that 'at the heart of the intractable political opposition ... was Sind's ongoing opposition to all new works on the Indus river itself. ${ }^{40}$ But reducing environmental disaster to provincial disputes sidesteps the severity of change, which at a community level is distilled to a question of place and identity. One person illustrated this change poignantly in the following way: 'Once when people from

\footnotetext{
${ }^{36}$ Ali, The Punjab Under Imperialism, esp. Ch. 1.

${ }^{37}$ Gilmartin, Blood and Water, 144-5.

${ }^{38}$ Colonial hydrology in what is now Pakistan was not limited to the Punjab. In 1932, the Sukkur barrage was built on the Indus in northern Sindh. The Sukkur barrage scheme was a series of perennial canals built in order to increase land under cultivation and to open Sindh to a cash crop economy. See: (Gilmartin, Blood and Water, 184-5).

${ }^{39}$ Majed Akhter has argued that in the post-colonial state, dam construction served another purpose: for the militarybureaucratic establishment, massive infrastructure projects, such as the Tarbela dam, attempted to consolidate Pakistani space as homogenous and undifferentiated (Akhter 2015). In fact, as Akhter notes, it has had the opposite effect, which is corroborated in my interviews as well.

${ }^{40}$ Gilmartin, Blood and Water, 234 (emphasis in the original). See also: Daanish Mustafa, "Hydropolitics in Pakistan's Indus basin," United States Institute of Peace Special Report (2010):

https://www.usip.org/sites/default/files/resources/SR261\%20-\%20Hydropolitics_in_Pakistan\%27s\%20_Indus_Basin.pdf [Accessed: 21 Sep. 2020].
} 
the delta were asked where they are from they would say we come from a place where the river flows into the sea. Nowadays when the same question is asked, we say we are from the place where the sea flows into the river. ${ }^{41}$ Water levels in the delta depend on how much water is released upriver, and equally importantly, when. People who continue to practice agriculture in the delta describe how the spring cultivation season has move forward to later in the summer, which means that the little commercial harvest that there is comes onto the market in the middle of winter, at least three months after the national distribution networks have been satiated.

\section{FUTURE}

In 2010, a Zulfiqarabad Development Authority was constituted and tasked with planning, building and operating a new namesake port city, Zulfiqarabad, in Thatta district in the Indus delta. The planned port city was to be built 150 kilometers south and to the east of Karachi, and would extend over four existing subdistricts: Gharo Chan, Keti Bunder, Shah Bander and Jati. Although Zulfiqarabad was a new name, this was not the first time that a large-scale development project was planned for the delta. In 1995, plans first appeared for the construction of a thermal power plant at Keti Bunder, and the setting up of small industries in the vicinity. ${ }^{42}$ This had been during the first tenure of Prime Minister Nawaz Sharif (1993-1996). Over the next quarter century, the Indus delta would see three separate plans for large-scale infrastructure development: in 2007, in 2010, and in 2016, each coinciding with a different government. The ethos behind these plans has always been similar: a certainty brought on by infrastructure planning, that one can construct - in the most literal sense of the word - a better future. This has been described as the 'promise of material infrastructure,' where infrastructure is a harbinger of development and modernity by being able to differentiate between the 'experiences of everyday life' and 'expectations of the future. ${ }^{43}$

For Pakistan's then-military junta and their technocratic planners, 2006-2007 appeared as a turning point. It was during a visit to Karachi that Prime Minister Shaukat Aziz hinted that the feasibility of port development at Keti Bunder was being considered. ${ }^{44}$

\footnotetext{
${ }^{41}$ Author interview, 2019.

${ }^{42}$ Guriro, "Keti Bunder."

${ }^{43}$ Hannah Appel, Nikhil Anand, and Akhil Gupta. "Introduction: Temporality, politics, and the promise of infrastructure," in The Promise of Infrastructure, eds. Nikhil Anand, Akhil Gupta, and Hannah Appel (Durham: Duke University Press, 2018), 3.

44 “Keti Bandar project may be revived," Dawn (22 Mar. 2007): https://www.dawn.com/news/238651/keti-bandar-projectmay-be-revived [Accessed: 26 Aug. 2019].
} 
Aziz was a former New York-based Citi Banker handpicked initially as Finance Minister, and then as Premier during General Pervez Musharraf's regime. Temporally, the suggestion that a port be constructed at Keti Bunder was coterminous with renewed interest in Pakistan's transit potential, which in turn coincided with a lull in fighting in neighbouring Afghanistan. ${ }^{45}$ But the moment did not last: by mid-summer 2007, Pakistan found itself in the throes of Islamist militancy, the Pakistani Taliban secured control over large swathes of the Swat valley in the north, and perhaps most crucially, the economy collapsed, taking with it both the military regime, and technocratic dreams of connecting Pakistan to a wider Asia.

The following year, a civilian government led by the Pakistan People's Party (20082013) came to power. Plans for reviving the fortunes of the Indus delta resurfaced. The development project now took the name Zulfiqarabad (after the founder of the Pakistan People's Party and prime minister who had been executed in 1979 following a military coup). According to then President Asif Ali Zardari, Zufliqarabad was to be modelled on Shenzhen, complete with a special economic zone. ${ }^{46}$ As early as 2012, Chinese, Czech and Turkish construction firms were said to have expressed interest in building the city, although interest in the project ebbed when the Pakistan People's Party lost power at the federal level in the next election.

The latest iteration of port planning was in 2016, when it was proposed in planning circles that port development at Keti Bunder be included in the China-Pakistan Economic Corridor (CPEC). ${ }^{47}$ Announced in 2013, CPEC is a framework for up to $\$ 60$ billion investment in connectivity infrastructure, energy generation and special economic zones in Pakistan variously financed by the Chinese government, Chinese SOEs, as well as private Chinese investors. But people I have interviewed as late as August 2019 affirm

\footnotetext{
45 The previous year, in 2006, Musharraf and Aziz had inaugurated a dry port at Sost on the Pakistan-China border. At the inauguration of the dry port, Musharraf had spoken extensively about Pakistan's transit potential ("Karakoram highway's Gwadar link likely," Dawn (5 July 2006): https://www.dawn.com/news/200132 [Accessed: 10 Sep. 2019]). Less than a year later, Aziz appeared to be propagating similarly reductionist thinking, whereby Pakistan saw itself ideally positioned to leverage its position on the crossroads of Asia by facilitating movement of cargo between Afghanistan and Central Asia on the one hand, and the global markets via connectivity to Indian Ocean ports, on the other ("Keti Bandar project may be revived").

46 "Chinese agree to build Zulfiqarabad city on Shenzhen model, president told," Pakistan Today (31 May 2012): https://www.pakistantoday.com.pk/2012/05/31/chinese-agree-to-build-zulfikarabad-city-on-shenzhen-model-president-told/ (Accessed: 30 Dec. 2019).

${ }^{47}$ Hamid Khan Wazir, "Government to include Keti Bunder, FATA in CPEC: Senator Mushahid," Pakistan Today (16 Dec. 2016): https://www.pakistantoday.com.pk/2016/12/19/government-to-include-keti-bunder-fata-in-cpec-senator-mushahid/ [Accessed: 26 Aug. 2019].
} 
that, as of yet, there has been no port development in the delta under the ambit of CPEC. ${ }^{48}$ This proposal then is likely a case of politicians and technocrats attempting to hitch development plans onto what they see as the most likely source of finance; today this is investment from China.

There is a high degree of ambivalence about port development in the Indus delta; many locals have been steadfastly opposed to the idea. Contrary to the meta-narratives propagated by the state, which seek to project the Indus delta as becoming the next Dubai or Shenzhen, people who live in the region point to the loss of land to salination, encroaching seawater, disappearing mangroves, and the steady migration out of the delta. For the people of the delta, memories of a past in which there was water in the delta continue to circulate. The lack of access to natural resources that the land and river once provided and enabled create vulnerabilities. Although economically marginalized and living precariously, local understandings of the changes around them are modern and informed. People I spoke with talk of water levels in the Indus, disappearing mangroves, salination. ${ }^{49}$ Where the state narrative is one of tapping into market networks through new infrastructure development, people of the delta look to the past where there was an abundance of public goods: arable land, local produce, water. The past helps them to calibrate their expectations of a just present.

Here we have two competing visions of what development is, and who it is for. For delta inhabitants, the primary concern is the lack of water. The environmental devastation due to lack of water is well-known amongst state officials. Indeed, water scarcity in the delta has been raised in official arbitration with India over water levels in the Indus; it also features in the inter-provincial debates over up-river hydrology ${ }^{50}$ And yet, there are few concrete steps taken that would address the vulnerability of delta inhabitants. The tacit understanding, two separate Karachi-based development professionals told me, is that the state has decided to let the delta run dry. ${ }^{51}$ Put simply, the political divisions that have led to water scarcity in the delta are insurmountable.

\footnotetext{
${ }^{48}$ In recent years, the Belt and Road Initiative (BRI) and Beijing's investments in connectivity infrastructure have fueled yearning for spectacular development across Africa and Asia. Interestingly, plans for port construction predate BRI; this temporality, that is the predating of BRI, underscores the allure of the port city as a developmentalist aspiration, once Dubai and Singapore, and more recently Shanghai and Shenzhen. In Pakistan's development schema, major Asian port cities are seen as spaces made by outward radiating networks of flowing and (crucially) accessible capital.

${ }^{49}$ Author interviews, 2018-20.

${ }^{50}$ Rabia Aslam, "Pakistan's water vulnerability and the risk of inter-state conflict in South Asia," Forman Journal of Economic Studies, 9 (2013), 19-41; Mustafa, "Hydropolitics in Pakistan's Indus basin;" Raman, "Damming and infrastructural development," 1-31.

${ }^{51}$ Author interviews, 2019.
} 
While this may be conjecture, what we can see is how, since the turn of the century, technocrats have emphasized development of mega-infrastructure. The state has opted for a neoliberal developmentalist imaginary - set in an unknown time in the future - as opposed to addressing environmental degradation, which is what has led to the precarious livelihoods of today. But many locals consider the proposed infrastructure development as non-consultative, akin to land-grabbing and in violation of their right to selfdetermination; the displacements that will surely follow in the event of large-scale development are argued to be in violation of the Universal Declaration of Human Rights. ${ }^{52}$

Such types of opposition have been described as 'moral ecology, that is, mobilization against infrastructural incursion that is seen as detrimental to community wellbeing and local livelihoods. ${ }^{53}$ The proposed port infrastructure becomes a contested terrain, underlying which are contestations of power. Driving towards Keti Bunder, one of the local people we were traveling with waved towards a desolate tract of land. 'This is where Zulfiqarabad is supposed to be built.' After a moment's pause, he said quietly, 'We won't let them.' Seeing the surprised look on my face, he explained: 'There are hundreds of thousands of people who live out here, in this wilderness. If you build Zulfiqarabad those people will be displaced. Where does the state propose to go and dump them?'54

\section{Conclusion}

In this article, I explored the tension between precarious livelihoods in the Indus delta and neoliberal development imaginaries that rest on state aspirations for a connected port city. There are implications here, I think, for policy beyond the Indus delta, especially in the discord between community and state ideas of development and well-being.

For the state, development is often projected as being connected to a networked Asia; in how they are imagined, port cities are seen as gateways for transnational capital and finance. This is a neoliberal future; beyond the Indus delta, it explains the current fixation with the Gwader port and Pakistan's dependency on China as enabling this crucial linking infrastructure. But traditionally, people did not build association with place through infrastructure: it was through access to commons, public goods, and community wellbeing. No one I spoke with said they looked forward to one day being a crane operator

\footnotetext{
52 Indus Delta: An environmental assessment.

${ }^{53}$ Caterina Scaramelli, "The delta is dead: Moral ecologies of infrastructure in Turkey," Cultural Anthropology, 34,3 (2019), 388-416; Mubbashir Rizvi, "The moral ecology of colonial infrastructure and the vicissitudes of land rights in rural Pakistan," History and Anthropology, 28, 3 (2016), 308-25.

${ }^{54}$ Author Interview, 2020.
} 
or a forklift driver, although this is not to preclude the fact that people everywhere aspire to a better material future. Instead, their demands were more immediate, and grounded: a metal road, water for drinking and irrigation, adequate health facilities. From neighbouring Baluchistan to Nigeria's Ogoniland, claims to alleviate local poverty and to provide basic services have become the calling card of transnational corporations building infrastructure. But one does not need a port to be built before basic public services are materialized. En route to Keti Bunder, we came across a 'Long March,' locals protesting against the lack of metal road. It was a simple enough demand, which no one could argue with.



Fig. 5. "Long Marchers" demanding construction of a metal road. Photo courtesy of the author.

A recent study commissioned by the World Bank, on how Pakistan might look at a hundred in the year 2047, asks the reader to imagine Pakistan celebrating its centenary 'at a time when the country's major port and trading hub, Karachi is able to compete with the likes of Dubai, Shanghai or Singapore.' The report then goes on to describe networked 
cities that are green, eco-friendly and linked by high-speed rails and state-of-the-art roads. People would live close to parks, schools, sports-facilities and libraries, and the cities would be crime-free. This utopia can be realized, according to the World Bank's local consultants, if Pakistan embraces 'more open trade and regional integration.' Better regional integration could increase the size of Pakistan's economy by $30 \%$ by $2047 .{ }^{55}$

At the heart of this neoliberal futuristic projection is a simple proposition: with the correct infrastructure, a free-market ethos, and some geographic serendipity, even an environmentally devastated region such as Keti Bunder can become a portal for wealth and prosperity. In the minds of technocratic planners, the port is the quintessential networked space that will engender a leap in Pakistan's current development trajectory. And yet lost in this imaginary of future development is the steady environmental degradation that has been underway for a century. Somewhat ironically, this environmental degradation was itself a consequence of an earlier epoch of infrastructure development, and which today results in poverty and precarity, and which has left the delta of the Indus - one of Asia's mightiest rivers, and a once connected, thriving Indian Ocean locale — desolate and dry.

\footnotetext{
${ }^{55}$ World Bank, Pakistan@ 100: Shaping the future (Washington DC: The World Bank, 2019): https://openknowledge.worldbank.org/bitstream/handle/10986/31335/Pakistanat100Overview.pdf?sequence=3\&isAllowed= y [Accessed: 29 Aug. 2019], 2-3.
} 